\title{
Mechanisms affecting exercise ventilatory inefficiency-airflow obstruction relationship in male patients with chronic obstructive pulmonary disease
}

Ming-Lung Chuang ${ }^{1,2}$ (D)

\begin{abstract}
Background: Exercise ventilatory inefficiency is usually defined as high ventilation (VE) versus low $\mathrm{CO}_{2}$ output (VCO2). The inefficiency may be lowered when airflow obstruction is severe because VE cannot be adequately increased in response to exercise. However, the ventilatory inefficiency-airflow obstruction relationship differs to a varying degree. This has been hypothesized to be affected by increased dead space fraction of tidal volume $\left(V_{D} N_{T}\right)$, acidity, hypoxemia, and hypercapnia.

Methods: A total of 120 male patients with chronic obstructive pulmonary disease were enrolled. Lung function and incremental exercise tests were conducted, and VE versus VCO2 slope (VE/ NCO2S) and intercept (VE/VCO2I) were obtained by linear regression. Arterial blood gas analysis was also performed in 47 of the participants during exercise tests. $V_{D} N_{T}$ and lactate level were measured.

Results: $V_{D} N_{\text {Tpeak }}$ was moderately positively related to $\operatorname{VE} / \mathrm{V} C O 2 S(r=0.41)$ and negatively related to forced expired volume in $1 \mathrm{sec} \%$ predicted $\left(\mathrm{FEV}_{1} \%\right)(r=-0.27)$, and hence the $\mathrm{FEV}_{1} \%$ - $\mathrm{VE} / \dot{\mathrm{V} C O} 2 \mathrm{~S}$ relationship was paradoxical. The higher the $\dot{V}$ /NCO2S, the higher the $\mathrm{pH}$ and $\mathrm{P}_{\mathrm{a}} \mathrm{O}_{2}$, and the lower the $\mathrm{P}_{2} \mathrm{CO}_{2}$ and exercise capacity. $\mathrm{VE} / \mathrm{V} C O 2 \mathrm{l}$ was marginally related to $V_{D} N_{\text {Trest. }}$ The higher the $\dot{V} E / V_{C O}$ l, the higher the inspiratory airflow, work rate, and end-tidal $\mathrm{PCO}_{2 \text { peak. }}$

Conclusion: 1) Dead space ventilation perturbs the airflow- VE/VCO2S relationship, 2) increasing ventilation thereby increases VE/NCO2S to maintain biological homeostasis, and 3) the physiology- VE/ NCO2S- VE/NCO2I relationships are inconsistent in the current and previous studies.

Trial Registration: MOST 106-2314-B-040-025.

Keywords: Incremental exercise test, Obstructive airway disease, Dead space and tidal volume ratio, Ventilatory equivalents for oxygen and $\mathrm{CO}_{2}$, Slope for ventilation versus $\mathrm{CO}_{2}$ output, Intercept for ventilation versus $\mathrm{CO}_{2}$ output
\end{abstract}

Correspondence: yuan1007@ms36.hinet.net

'Department of Internal Medicine and Division of Pulmonary Medicine, Chung Shan Medical University Hospital, \#110, Section 1, Chien-Kuo North

Road, South District, Taichung 40201, Taiwan, Republic of China

${ }^{2}$ School of Medicine, Chung Shan Medical University, Taichung 40201,

Taiwan, Republic of China

(c) The Author(s). 2020 Open Access This article is licensed under a Creative Commons Attribution 4.0 International License, which permits use, sharing, adaptation, distribution and reproduction in any medium or format, as long as you give appropriate credit to the original author(s) and the source, provide a link to the Creative Commons licence, and indicate if changes were made. The images or other third party material in this article are included in the article's Creative Commons licence, unless indicated otherwise in a credit line to the material. If material is not included in the article's Creative Commons licence and your intended use is not permitted by statutory regulation or exceeds the permitted use, you will need to obtain permission directly from the copyright holder. To view a copy of this licence, visit http://creativecommons.org/licenses/by/4.0/ The Creative Commons Public Domain Dedication waiver (http://creativecommons.org/publicdomain/zero/1.0/) applies to the data made available in this article, unless otherwise stated in a credit line to the data. 


\section{Background}

High ventilatory equivalents for oxygen and $\mathrm{CO}_{2}$ ( $\dot{\mathrm{VE}} / \dot{\mathrm{VO}} 2$ and $\dot{\mathrm{VE}} / \dot{\mathrm{VCO}} 2$ ) have been shown to be indexes of uneven alveolar ventilation-perfusion ratio ( $\dot{V A} / \dot{Q})$ [1] and markers of ventilation inefficiency caused by both heart and lung diseases [2]. The VE/ $\dot{V} C O 2$ slope ( $\dot{V E} / \dot{V} C O 2 S)$ is elevated in dyspneic patients and can differentiate congestive heart failure (CHF) from chronic obstructive pulmonary disease

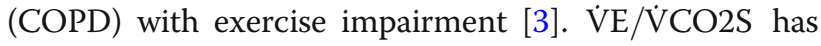
also been shown to be a marker of the severity and prognosis of CHF $[4,5]$ and an indicator of treatment response $[6,7]$, even though it cannot reflect the treatment effect in patients with CHF of different severity [8].

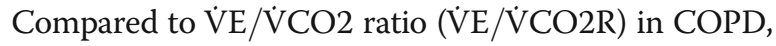
$\mathrm{VE} / \mathrm{VCO} 2$ intercept (VE/VCO2I) i.e. dead space ventilation $[9,10]$, has been shown to be a better indicator of exertional ventilatory inefficiency and unfavorable patient outcomes i.e. mechanical constraint, pulmonary gas exchange, exertional dyspnea, and exercise intolerance [11]. In patients with COPD, $\dot{\mathrm{VE}} / \mathrm{VCO} 2 \mathrm{~S}$ is negatively related to $\dot{\mathrm{VE}} / \dot{\mathrm{V} C O} 2 \mathrm{I}$ and decreases when airflow obstruction [11] and emphysema are severe [12]. However, in patients with COPD, the relationship between $\dot{\mathrm{VE}} / \mathrm{VCO} 2 \mathrm{~S}$ and forced expired volume in one $\mathrm{s} \%$ predicted $\left(\mathrm{FEV}_{1} \%\right)$ is weak $[3,11,13]$, although it is slightly better when Global Initiative for Chronic Lung Disease (GOLD) staging is used to grade the severity [11]. Similarly, in patients with $\mathrm{CHF}$ the slope is increased, however it decreases when the patients have airflow limitation [12] or when an external dead space is large enough to hamper $\dot{V E}$ compensation for hypercapnia [9].

Several mechanisms to explain overlapping $\dot{\mathrm{V}} / \dot{\mathrm{V} C O} 2 \mathrm{I}$ values across GOLD stage I to IV have been proposed [11]. These mechanisms include various afferent information from working limbs [14], peripheral chemoreceptors [15], pulmonary artery pressure, and $\mathrm{V}_{\mathrm{D}} / \mathrm{V}_{\mathrm{T}}$. However, no data or references have been reported for the last two factors [11].

In COPD, the lower the $\mathrm{FEV}_{1} \%$, the lower the $\mathrm{VE} / \mathrm{VCO} 2 \mathrm{~S}[11,13]$, and the lower the $\mathrm{FEV}_{1} \%$, the larger the $V_{\mathrm{D}} / \mathrm{V}_{\mathrm{T}}[16,17]$. In contrast, the larger the $\mathrm{V}_{\mathrm{D}} / \mathrm{V}_{\mathrm{T}}$, the higher the $\dot{V E} / \dot{V} C O 2 S[1,18]$. In this context, $\mathrm{VE} / \mathrm{VCO} 2 \mathrm{~S}$ may be high or low at a given $\mathrm{FEV}_{1} \%$. Hence, we hypothesized that the positive but weak relationship between $\mathrm{VE} / \dot{\mathrm{VCO}} 2 \mathrm{~S}$ and $\mathrm{FEV}_{1} \%$ may be influenced by $\mathrm{V}_{\mathrm{D}} / \mathrm{V}_{\mathrm{T}}$. We also evaluated other factors that may influence the relationship including hypoxemia and/or metabolic and/or respiratory acidity. This study aimed to elucidate the mechanisms underpinning the unclear relationship between $\mathrm{FEV}_{1} \%$ and $\mathrm{VE} / \dot{\mathrm{VCO}} 2 \mathrm{~S}$ and between $\dot{\mathrm{VE}} / \dot{\mathrm{VCO}} 2 \mathrm{~S}$ and exercise biological homeostasis.

\section{Methods}

Study design

We conducted an observational cross-sectional study on incremental maximal exercise in subjects with COPD at our institution. To obtain invasive measurement data, arterial catheterization was established for blood gas sampling in a subgroup of the participants. Each subject signed informed consent before entering the study. The local Institutional Review Board of our institutions (CS19014) approved this study. This study was conducted in compliance with the Declaration of Helsinki.

\section{Subjects}

We enrolled subjects aged $\geq 40$ years with COPD but without any chronic diseases including uncontrolled diabetes mellitus, uncontrolled hypertension, anemia (hemoglobin $<13 \mathrm{~g} \cdot \mathrm{dL}^{-1}$ in males), and no acute illnesses in the recent 1 month. The $\mathrm{FEV}_{1}$ /forced vital capacity (FVC) was < 0.7 [19]. The diagnosis of COPD was made by pulmonologists according to the GOLD criteria [19]. All of the participants had to be able and willing to perform the study protocol including a maximal or symptom-limited cardiopulmonary exercise test (CPET). All of the participants were regularly followed-up at our pulmonary outpatient clinics and received optimized and individually tailored drug treatment, and they all had a stable clinical condition for at least 1 month.

We excluded subjects with a body mass index $\leq 18$ $\mathrm{kg} \cdot \mathrm{m}^{-2}$ or $\geq 32 \mathrm{~kg} \cdot \mathrm{m}^{-2}$ and those with laboratory findings of hematological, metabolic or neuromuscular diseases, as these factors may confound exercise performance. Subjects with coexisting heart failure with/ without documented pulmonary embolism, primary valvular heart disease, pulmonary artery hypertension, pericardial disease, exercise-induced angina, ST changes, and severe arrhythmias were also excluded. As few female subjects meet the criteria of COPD in Taiwan [20], they were not included in this study. We also excluded those who had contraindications to perform the exercise test and those who were participating in exercise training. However, recreational activity was allowed.

\section{Measurements \\ Demographic and anthropometric data}

Age, height, weight, body mass index, and cigarette consumption were recorded.

\section{Functional daily activity}

The oxygen-cost diagram (OCD) was used to evaluate the participants' functional activity. The participants were asked to indicate a point on an OCD, a 10-cm long vertical line with everyday activities listed alongside the line, above which breathlessness limited them [21]. The distance from zero was measured and scored. 


\section{Pulmonary function testing}

Cigarette smoking, drinking coffee, tea, or alcohol, and taking medications were not permitted $24 \mathrm{~h}$ before any test. Bronchodilators were not administered within $3 \mathrm{~h}$ for short-acting beta agonists and $12 \mathrm{~h}$ for long-acting beta agonists before the tests [22, 23]. $\mathrm{FEV}_{1}$, FVC, total lung capacity (TLC), residual volume $(\mathrm{RV})$, and diffusing capacity for carbon monoxide $\left(D_{\mathrm{L}} \mathrm{CO}\right)$ were measured using spirometry, body plethysmography and the single-breath technique (MasterScreen $^{\text {tx }}$ Body, Carefusion, Wuerzburg, Germany), respectively in accordance with the currently recommended standards $[24,25]$. The best of three technically satisfactory readings was used [24, 26, 27]. All of the spirometry data were obtained before and after inhaling $400 \mu \mathrm{g}$ of fenoterol $\mathrm{HCl}$. Post-dose measurements were performed $15 \mathrm{~min}$ after inhalation. Static lung volume data and $\mathrm{D}_{\mathrm{L}} \mathrm{CO}$ data were obtained before inhaling fenoterol. For details, please refer to reference [22].

\section{CPET}

Each subject completed pulmonary gas exchange measured at rest and during exercise on the different days within 1 month after lung function test. Short-acting and long-acting beta bronchodilators were withheld 4-6 $\mathrm{h}$ and $\geq 12 \mathrm{~h}$ before the test, respectively. Gas exchange equipment including a face mask connected to a turbine pneumotachograph was used to measured $\mathrm{VO} 2(\mathrm{~mL} /$ $\mathrm{min}), \mathrm{CO}_{2}$ output $(\mathrm{V} \mathrm{CO} 2)(\mathrm{mL} / \mathrm{min})$, minute ventilation $(\mathrm{VE})(\mathrm{L} / \mathrm{min})$, tidal volume $\left(\mathrm{V}_{\mathrm{T}}\right)(\mathrm{L})$, breathing frequency (b/min), and end-tidal $\mathrm{PCO}_{2}\left(\mathrm{P}_{\mathrm{ET}} \mathrm{CO}_{2}\right)(\mathrm{mm} \mathrm{Hg})$ breathby-breath (MasterScreen CPX ${ }^{\mathrm{nw}}$, Carefusion, Wuerzburg, Germany), and then the data were averaged and reported at 15-s intervals of each stage using a computer. For each test, 12-lead electrocardiograms were recorded, pulse oximetry was used to record arterial oxyhemoglobin saturation $\left(\mathrm{S}_{\mathrm{P}} \mathrm{O}_{2}, \%\right)$, and a sphygmomanometer was used to measure blood pressure every 2 min. An electromagnetically braked cycle ergometer (Lode, Groningen, the Netherlands) was used to adjust workload via a computer. The exercise test protocol was a 2-min period of rest followed by 2-min period of unloaded exercise, followed by ramp-pattern loaded exercise with a workload per stage selected according to the oxygen-cost diagram so that the loaded exercise could be completed within $10 \pm 2 \mathrm{~min}$ of each participant reaching the limit of symptoms [28]. During each test, a pedaling frequency of $60 \mathrm{rpm}$ was maintained with the aid of a visual pedal rate indicator. Calibrations of the turbine pneumotachograph were performed using a 3-L syringe before each test. The $\mathrm{O} 2$ and $\mathrm{CO} 2$ analyzers were calibrated with standard gases.

\section{Calculation of $\dot{V} E / \dot{V} C O 2 S$ and $\dot{V} E / \dot{V} C O 2 R$}

Linear regression was used to quantify the relationship between $\mathrm{VE}$ and $\mathrm{VCO} 2$ to obtain $\mathrm{VE} / \mathrm{VCO} 2 \mathrm{~S}$ and $\mathrm{VE} / \mathrm{VCO} 2 \mathrm{I}$. For linear regression, data of the entire loaded exercise [5] were used if the respiratory or ventilatory compensation point ( $\mathrm{RCP}$ or $\mathrm{VCP}$ ) [1, 29] were not identified by $\mathrm{P}_{\mathrm{ET}} \mathrm{CO}_{2}$ curve; data below the $\mathrm{RCP}$ were used if the $\mathrm{RCP}$ or $\mathrm{VCP}$ was identified. $\mathrm{P}_{\mathrm{ET}} \mathrm{CO}_{2}$ curve reveals slow increase from start of exercise to anaerobic threshold and is then relatively stable during isocapneic buffering period. After the period, $\mathrm{P}_{\mathrm{ET}} \mathrm{CO}_{2}$ starts to decrease where RCP is defined. To be noted, RCP was reported in four of 16 subjects with pulmonary emphysema in a previous study [12]. $\dot{V}$ /VCO2R was directly calculated. $\dot{\mathrm{VE}} / \mathrm{VCO} 2$ nadir $(\mathrm{VE} / \mathrm{VCO} 2 \mathrm{~N})$ was the lowest value of $\mathrm{VE} / \mathrm{VCO} 2 \mathrm{R}$ during loaded exercise period [30].

\section{$V_{D} / V_{T}$ measurement}

Brachial artery catheterization was established and blood samples were drawn and heparinized in a subgroup of the participants at rest and at the last $15 \mathrm{~s}$ of every minute during loaded exercise and at peak exercise. The sample was immediately placed on ice and then analyzed for $\mathrm{pH}, \mathrm{PCO}_{2}$, and $\mathrm{PO}_{2}$ with body temperature correction (model 278, CIBA-Corning, Medfield, MA, USA). The $V_{\mathrm{D}} / \mathrm{V}_{\mathrm{T}}$ was calculated using a standard formula as follows [31].

$$
V_{D} / V_{T}=\left(P_{a} C O_{2}-P \overline{\mathrm{E}} C \mathrm{O}_{2}\right) / P_{a} C O_{2}-V_{D} m / V_{T}
$$

where $\mathrm{P} \overline{\mathrm{E}} \mathrm{CO}_{2}=\dot{\mathrm{VCO}} 2 / \mathrm{VE} \times\left(\mathrm{P}_{\mathrm{B}}-47 \mathrm{mmHg}\right)$ and $\mathrm{PB}$ was barometric pressure measured daily and $\mathrm{V}_{\mathrm{D}} \mathrm{m}$ was the dead space of mouth piece and pneumotachograph as the manufacture reported.

\section{Statistical analysis}

Data were summarized as mean \pm standard deviation. Comparisons between two groups were performed using two-sample t test. Pearson's or Spearman's correlation coefficients were used when appropriate for quantifying the pair-wise relationships among the interested continuous variables. Statistical significance was set at $p \leq 0.05$.

Marginal statistical significance was set at $0.05<p<$ 0.1 .

\section{Results}

A total of 120 male subjects with COPD aged $67.0 \pm 6.8$ years were enrolled after excluding nine subjects aged $\geq 80$ years (Fig. 1 and Table 1). Most of the participants had moderate to severe disease severity. Overall, 118 subjects completed the exercise test after excluding two who had poor motivation (Table 1). In the entire group and its 


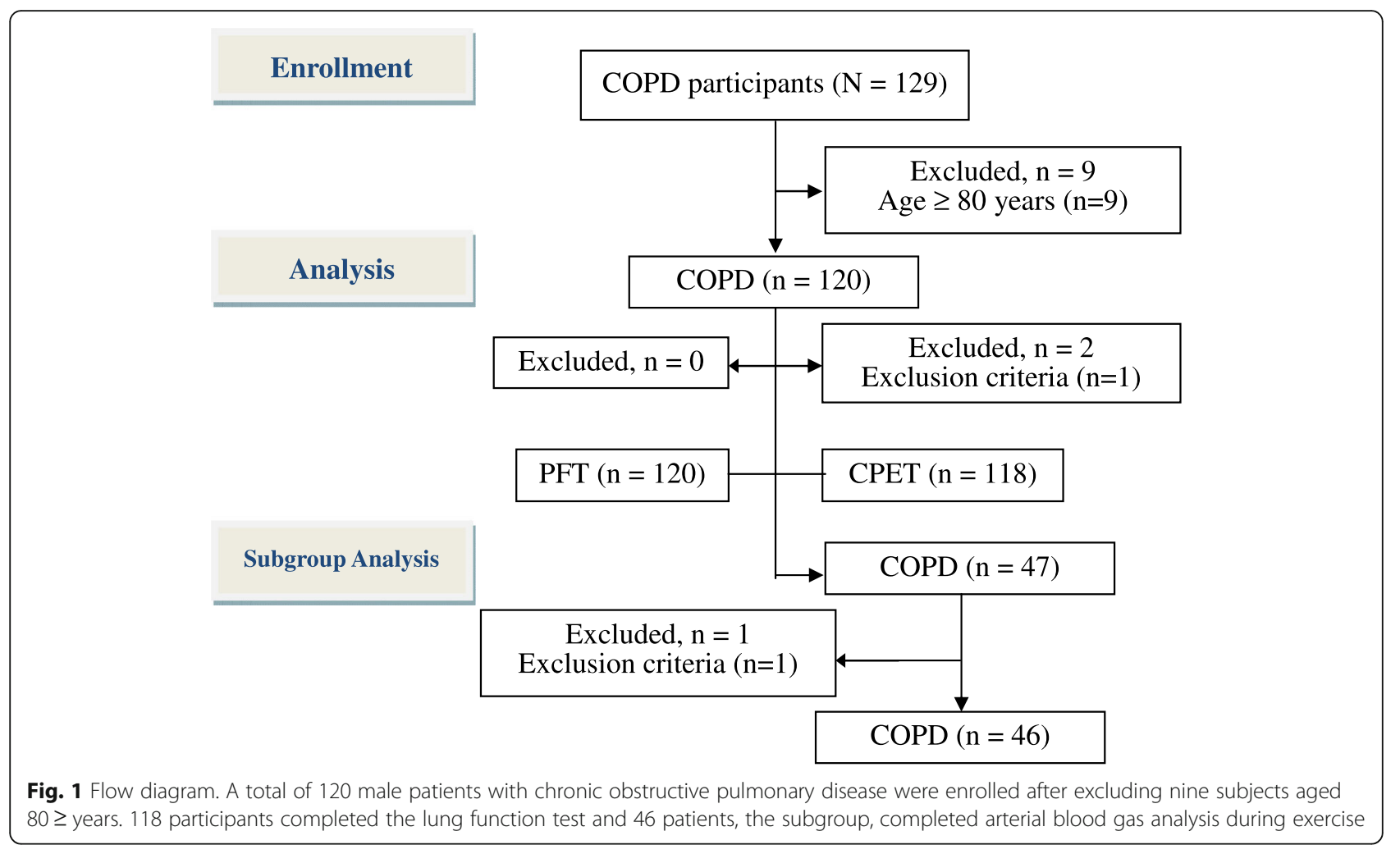

subgroup of patients who underwent blood gas sampling, $\dot{\mathrm{VE}} / \mathrm{VCO} 2 \mathrm{~S}$ and $\dot{\mathrm{VE}} / \dot{\mathrm{V} C O} 2 \mathrm{I}$ were moderately negatively related (Table 2, $r=-0.40--0.44, p<0.001-<0.0001$ ). The relationships between $\mathrm{VE} / \mathrm{VCO} 2 \mathrm{~S}$ and the pulmonary physiology variables of interest were similar to some extent between the entire group and the subgroup of patients who underwent blood gas sampling (Table 2).

$\dot{V} E / \dot{V} C O 2 S$ versus Pulmonary Physiology and Exercise Capacity. $\mathrm{VE} / \mathrm{VCO} 2 \mathrm{~S}$ was related to a varying degree to expiratory flow $(r=0.20-0.42, p<0.05-<0.01)$, and marginally related to inspiratory flow. $\dot{\mathrm{V}} / \mathrm{V} \mathrm{VO} 2 \mathrm{~S}$ was not related to any of the volume excursion variables at peak exercise except for $\mathrm{V}_{\mathrm{T}} / \mathrm{FEV}_{1}$ in the subgroup analysis (Table $2, r=-0.32, p<0.05$ ). $\mathrm{VE} / \mathrm{VCO} 2 \mathrm{~S}$ was positively related to an increase in $\mathrm{S}_{\mathrm{P}} \mathrm{O}_{2} \quad(r=0.32-0.50)$. $\dot{\mathrm{V} E} / \mathrm{VCO} 2 \mathrm{~S}$ was mildly negatively related to $\dot{\mathrm{VO}} 2$ peak $\%$ $(r=-0.27--0.33)$. In the subgroup of patients who underwent blood gas sampling, at peak exercise, $\mathrm{VE} / \mathrm{VCO} 2 \mathrm{~S}$ was moderately positively related to $\mathrm{pH}$ and $\mathrm{P}_{\mathrm{a}} \mathrm{O}_{2}$ (Table 3, $r=0.40-0.53$ ), and strongly negatively related to $\mathrm{P}_{\mathrm{a}} \mathrm{CO}_{2}$ and $\mathrm{P}_{\mathrm{ET}} \mathrm{CO}_{2}$ (Tables 2 and 3, $r=-0.60$ -0.62).

In the subgroup of patients who underwent blood gas sampling, with regards to pulmonary physiology variables, $V_{\mathrm{D}} / \mathrm{V}_{\text {Tpeak }}$ was moderately positively related to $\mathrm{VE} / \mathrm{VCO} 2 \mathrm{~S}$, and marginally negatively related to $\mathrm{FEV}_{1} \%$ (Table 2 and Fig. 2, $r=-0.27, p=0.08$ ).
VE/VCO2I versus Pulmonary Physiology and Exercise Capacity. $\dot{\mathrm{V}} / \dot{\mathrm{V} C O} 2 \mathrm{I}$ was mildly related to inspiratory flow $(r=0.22-0.30, p<0.05)$, marginally to mildly related to $\dot{\mathrm{VO} 2}$ peak $\%$ (Table 2, $r=0.27-0.28$ ) and mildly to moderately related to Work $_{\text {peak }} \%$ (Table 2, $r=0.30$ 0.43 ), but not to expiratory flow or all volume excursion variables.

In the subgroup of patients who underwent blood gas sampling, $\mathrm{VE} / \dot{\mathrm{V} C O} 2 \mathrm{I}$ was moderately related to an increase in $\mathrm{P}_{\mathrm{ET}} \mathrm{CO}_{2}$ (Table 2, $r=0.53$ ) and marginally related to $\mathrm{V}_{\mathrm{D}} / \mathrm{V}_{\text {Trest }}(r=0.28, p=0.08)$, but not to $\mathrm{V}_{\mathrm{D}} /$ $\mathrm{V}_{\text {Tpeak }}$.

\section{Discussion}

The main findings of this study confirm that in male subjects with COPD, $\dot{V E} / \dot{V} C O 2 S$ was correlated to a varying degree with $\mathrm{FEV}_{1} \%$ and GOLD stage. We further found that $V_{D} / V_{\text {Tpeak }}$ was the main cause of the relationships (Fig. 2). A high VE/VECO2S improved arterial $\mathrm{pH}, \mathrm{PO}_{2}$, and $\mathrm{PCO}_{2}$, but was not caused by these factors. The findings support our hypothesis. Additionally, $\dot{V E} / \dot{V} C O 2 I$ was marginally related to dead space at rest and $\dot{V} O 2$ peak and significantly related to increases in inspiratory airflow, $\mathrm{P}_{\mathrm{a}} \mathrm{CO}_{2}$, and work rate.

$\dot{V} E / \dot{V} C O 2 S$ versus Pulmonary Physiology of COPD. The results revealed that expiratory airflow graded by 
Table 1 Subjects' characteristics, lung function, and exercise data $(n=120)$ versus the subgroup data $(n=47)$

\begin{tabular}{|c|c|c|c|c|c|}
\hline \multirow[t]{3}{*}{$N=$} & \multicolumn{2}{|l|}{ Total } & \multicolumn{3}{|c|}{ Subgroup } \\
\hline & Mean & SD & Mean & SD & $\mathrm{T}$ test \\
\hline & \multicolumn{2}{|l|}{120} & \multicolumn{3}{|l|}{47} \\
\hline Age, year & 67.0 & 6.8 & 65.3 & 5.7 & NS \\
\hline Height, cm & 164.8 & 5.7 & 165.1 & 6.4 & NS \\
\hline Weight, kg & 62.4 & 9.4 & 60.8 & 11.4 & NS \\
\hline Body mass index, $\mathrm{kg} / \mathrm{m}^{2}$ & 23.0 & 3.1 & 22.2 & 3.6 & NS \\
\hline Smoke, pack-year & 51.3 & 28.1 & 41.4 & 19.3 & 0.01 \\
\hline Oxygen-cost diagram, cm & 7.1 & 1.3 & 7.0 & 1.4 & NS \\
\hline Total lung capacity, TLCpred\% & 1.15 & 0.23 & 1.34 & 0.21 & $<0.0001$ \\
\hline Residual volume/TLC & 0.56 & 0.10 & 0.58 & 0.09 & NS \\
\hline $\mathrm{D}_{\mathrm{L}} \mathrm{CO} \%$ & 0.76 & 0.24 & 0.69 & 0.22 & NS \\
\hline Forced vital capacity, FVCpred\% & 0.83 & 0.20 & 0.81 & 0.21 & NS \\
\hline $\mathrm{FEV}_{1}$ pred\% & 0.57 & 0.18 & 0.50 & 0.19 & 0.06 \\
\hline GOLD I-IV, $n=$ & \multicolumn{2}{|c|}{$10,68,33,9$} & \multicolumn{3}{|c|}{$3,19,19,6$} \\
\hline $\mathrm{FEV}_{1} / \mathrm{FVC}$ & 0.53 & 0.12 & 0.49 & 0.13 & 0.1 \\
\hline Heart Rate $e_{\text {peak }} \%$ & 0.82 & 0.11 & 0.81 & 0.12 & NS \\
\hline Oxygen uptake, $\mathrm{VO}_{2 \text { peak }} \%$, & 0.69 & 0.20 & 0.69 & 0.21 & NS \\
\hline Respiratory exchange ratiopeak & 1.05 & 0.10 & 1.05 & 0.10 & NS \\
\hline Work $k_{\text {peak }} \%$ & 0.75 & 0.26 & 0.68 & 0.30 & NS \\
\hline $\mathrm{O}_{2}$ Pulse peak $\%$ & 0.83 & 0.22 & 0.85 & 0.23 & NS \\
\hline Minute ventilation, $V_{\text {Epeak, }} \mathrm{L} / \mathrm{min}$, & 43.6 & 13.1 & 38.6 & 12.3 & 0.02 \\
\hline$V_{E \text { peak }} / M W$ & 1.00 & 0.30 & 1.16 & 0.36 & $<0.01$ \\
\hline $\mathrm{V}_{\mathrm{E}} / \mathrm{NCO}_{2 \text { nadir }}$ & 38.6 & 7.8 & 35.0 & 6.9 & $<0.01$ \\
\hline $\mathrm{V}_{\mathrm{E}} \mathrm{NCO}_{2}$ Slope & 33.7 & 7.5 & 29.9 & 5.7 & $<0.001$ \\
\hline $\mathrm{V}_{\mathrm{E}} \mathrm{NCO}_{2}$ Intercept & 5.2 & 1.8 & 5.2 & 1.6 & NS \\
\hline $\mathrm{S}_{p} \mathrm{O}_{2 \text { peak, }} \%$ & 92.2 & 5.4 & 91.0 & 5.8 & NS \\
\hline Tidal volume, $V_{\text {Tpeak }} / T L C$ & 0.22 & 0.06 & 0.19 & 0.05 & $<0.01$ \\
\hline $\mathrm{V}_{T} /$ Inspiratory time, $\mathrm{T}_{\text {Ipeak, }} \mathrm{L} / \mathrm{s}$ & 1.70 & 0.50 & 1.52 & 0.46 & 0.04 \\
\hline Breathing frequency $y_{\text {peak, }}, \mathrm{b} / \mathrm{min}$ & 33.5 & 6.1 & 32.6 & 5.9 & NS \\
\hline Breathing cycle time, $T_{\text {tot peak, }} \mathrm{S}$ & 1.85 & 0.33 & 1.89 & 0.31 & NS \\
\hline $\mathrm{T}_{\text {lpeak, }} \mathrm{S}$ & 0.78 & 0.16 & 0.78 & 0.13 & NS \\
\hline$\left.R S B\right|_{\text {peak, }}, \mathrm{b} / \mathrm{L}$ & 27.8 & 11.3 & 30.5 & 13.9 & NS \\
\hline
\end{tabular}

$D_{L} C O$ diffusing capacity for carbon monoxide, $F E V_{1}$ forced expired volume in 1 $\mathrm{s}, \mathrm{GOLD}$ global initiatives for chronic obstructive lung disease, $\mathrm{O}_{2} \mathrm{Pulse}^{\mathrm{\prime}} \mathrm{O}_{2} /$ heart rate, $M V V$ maximal voluntary ventilation, $\mathrm{S}_{\mathrm{P}} \mathrm{O}_{2}$ oxyhemoglobin saturation measured with pulse oximetry, $s$ second, $R S B I$ rapid shallow breathing index = breathing frequency/tidal volume

$\mathrm{FEV}_{1} \%, \mathrm{GOLD}$ stage, and $\mathrm{FEV}_{1} / \mathrm{VC}$ was related to $\mathrm{VE} / \mathrm{VCO} 2 \mathrm{~S}$ to a varying degree (Fig. 2 and Table 2, $|r|=0.20-0.44)$. This is in line with previous reports that in patients with heart and lung diseases, severe airflow impairment may limit $\dot{\mathrm{VE}} / \dot{\mathrm{V} C O} 2 \mathrm{~S}$ to compensate for metabolic acidosis during heavy exercise $[3,9,11,12]$. However, this notion is not consistent with the study by Teopompi et al., who reported that $\dot{\mathrm{VE}} / \mathrm{VCO} 2 \mathrm{~S}$ and
Table 2 Summary of correlation ( $r$ ) of VE/NCO2 slope (' $\mathrm{VE} / \mathrm{VCO} 2 \mathrm{~S})$ and its intercept (VE/VCO2I) with pulmonary physiology

\begin{tabular}{|c|c|c|c|c|}
\hline \multirow{2}{*}{$\begin{array}{l}r \\
N=\end{array}$} & \multicolumn{2}{|l|}{ Slope } & \multicolumn{2}{|c|}{$\underline{\text { Intercept }}$} \\
\hline & 118 & 46 & 118 & 46 \\
\hline Intercept & $-0.44^{\dagger}$ & $-0.40^{* *}$ & 1 & 1 \\
\hline \multicolumn{5}{|c|}{ Expiration } \\
\hline $\mathrm{FEV}_{1} \%$ & $0.20^{*}$ & $0.42^{* *}$ & -0.09 & -0.12 \\
\hline $\mathrm{FEV}_{1} / \mathrm{NC}$ & $0.27^{* *}$ & 0.15 & 0.02 & -0.02 \\
\hline GOLD & $-0.26^{* *}$ & $-0.44^{* *}$ & 0.08 & 0.11 \\
\hline \multicolumn{5}{|c|}{ Inspiration } \\
\hline$V_{T} / T_{\text {lpeak }}$ & $0.20^{n}$ & 0.03 & $0.22^{*}$ & $0.30^{*}$ \\
\hline \multicolumn{5}{|c|}{ Volume excursion/dynamic hyperinflation: } \\
\hline $\mathrm{V}_{\text {Tpeak }} / \mathrm{FEV}_{1}$ & -0.15 & $-0.32^{*}$ & 0.14 & 0.18 \\
\hline$V_{\text {Tpeak }} / I C$ & -0.15 & -0.05 & 0.15 & -0.00 \\
\hline$V_{\text {Tpeak }} N C$ & 0.01 & -0.04 & 0.02 & -0.04 \\
\hline$V_{\text {Tpeak }} / T L C$ & -0.01 & -0.06 & 0.10 & 0.13 \\
\hline \multicolumn{5}{|l|}{ Gas exchange: } \\
\hline $\mathrm{S}_{\mathrm{p}} \mathrm{O}_{2 \text { peak }}$ & $0.32^{* * *}$ & $0.50^{* * *}$ & 0.03 & -0.19 \\
\hline $\mathrm{P}_{\mathrm{ET}} \mathrm{CO}_{\text {2peak-rest }}$ & - & $-0.62^{\dagger}$ & - & $0.53^{* * *}$ \\
\hline$V_{D} / V_{\text {Trest }}$ & - & 0.03 & - & $0.28^{n}$ \\
\hline$V_{D} N_{\text {Tpeak }}$ & - & $0.41^{* *}$ & - & -0.23 \\
\hline \multicolumn{5}{|l|}{ Exercise capacity } \\
\hline VOO2 peak ${ }^{\ominus}$ & $-0.33^{* * *}$ & $-0.27^{\natural}$ & $0.28^{* *}$ & $0.27^{\natural}$ \\
\hline Work $_{\text {peak }}{ }^{\ominus}$ & -0.1 & $-0.3^{*}$ & $0.30^{* * *}$ & $0.43^{* *}$ \\
\hline
\end{tabular}

Abbreviations: $F E V_{1}$ forced expired volume in $1 \mathrm{~s}, V C$ vital capacity, GOLD stage of global initiatives for chronic obstructive lung disease, $V_{T} / T_{\text {lpeak }}$ the ratio of tidal volume and inspiratory time in second indicating mean inspiratory flow, IC inspiratory capacity, $T L C$ total lung capacity, $\mathrm{S}_{\mathrm{P}} \mathrm{O}_{2}$ oxyhemoglobin measured by pulse oximetry, $P_{E T} \mathrm{CO}_{2}$ end-tidal $\mathrm{CO}_{2}$ pressure, $\mathrm{V} O 2$ oxygen uptake

${ } \%$ of predicted maximum

-- not available

$" 0.05<p<0.1$

$* 0.05$

${ }^{* *}<0.01$

*** $\leq 0.001$

${ }^{\dagger}<0.0001$

$\mathrm{FEV}_{1} \%$ were not related (Supplementary Table) [13], although the role of inspiratory muscles was not considered. With regards to the tension time index of ventilatory muscle mechanics in normal healthy people and those with a disease, the inspiratory muscles may adapt to a level below or within the critical zone to sustain breathing in various conditions [32, 33]. As the mechanical load increases to a level which the inspiratory muscles can no longer tolerate, alveolar hypoventilation develops and the $\mathrm{P}_{\mathrm{a}} \mathrm{CO}_{2}$ point may be reset [34]. However, in the current study, mean inspiratory airflow was marginally related to $\mathrm{VE} / \mathrm{VCO} 2 \mathrm{~S}$ in the entire group and not significantly related to $\mathrm{VE} / \mathrm{VCO} 2 \mathrm{~S}$ 
Table 3 Three-factor interrelationships in 46 subjects with COPD

\begin{tabular}{|c|c|c|c|}
\hline \multicolumn{3}{|c|}{ Factor } & \multirow{2}{*}{ 3-factor interrelationships } \\
\hline F3 & $\mathrm{F} 1=\dot{\mathrm{V}}_{\mathrm{E}} / \dot{\mathrm{VCO}}_{2} \mathrm{~S} \longleftarrow r=0.42^{* *}$ & $\mathrm{~F} 2=\mathrm{FEV}_{1} \%$ & \\
\hline $\mathrm{V}_{\mathrm{D}} / \mathrm{V}_{\text {Tpeak }}$ & $0.41^{* *}$ & $-0.27^{\mathbb{I}}$ & Paradoxical: due to one $r+$ and one $r-$ \\
\hline $\mathrm{pH}_{\text {peak }}$ & $0.53^{\text {t }}$ & 0.02 & - \\
\hline $\mathrm{P}_{\mathrm{a}} \mathrm{O}_{2 \text { peak }}$ & $0.40^{* *}$ & $0.39^{* *}$ & Consistent: due to both $\mathrm{r}+$ \\
\hline $\mathrm{S}_{\mathrm{P}} \mathrm{O}_{2 \text { peak }}$ & $0.50^{* * *}$ & $0.29^{\$}$ & Consistent: due to both $r+$ \\
\hline $\mathrm{P}_{\mathrm{a}} \mathrm{CO}_{2 \text { peak }}$ & $-0.60^{\text {尔 }}$ & $-0.52^{\text {出 }}$ & Consistent: due to both $\mathrm{r}-$ \\
\hline Lactate $_{\text {peak }}$ & -0.13 & $0.34^{*}$ & - \\
\hline
\end{tabular}

in the subgroup, suggesting that mean inspiratory airflow was not sensitive enough to be related to $\mathrm{VE} / \mathrm{V} C \mathrm{COS}$.

However, expiratory airflow was related to $\dot{\mathrm{VE}} / \mathrm{V} C O 2 \mathrm{~S}$ to a varying degree, which may be explained by $V_{\mathrm{D}} / \mathrm{V}_{\mathrm{T}}$. In the current study, $\mathrm{V}_{\mathrm{D}} / \mathrm{V}_{\text {Tpeak }}$ was positively related to $\dot{V E} / \dot{V} C O 2 S$, similar to previous reports which used $\mathrm{VE} / \mathrm{VCO} 2 \mathrm{R}$ ranging from 31 to 40 in parallel with a $\mathrm{V}_{\mathrm{D}} /$ $\mathrm{V}_{\mathrm{T}}$ ratio ranging from 0.37 to 0.49 [16]. Combining the positive $\mathrm{V}_{\mathrm{D}} / \mathrm{V}_{\text {Tpeak }^{-}} \dot{\mathrm{VE}} / \mathrm{VCO} 2 \mathrm{~S}$ relationship with the positive $\mathrm{FEV}_{1} \%$ - $\dot{\mathrm{VE}} / \mathrm{VCO} 2 \mathrm{~S}$ relationship, it can be deduced that a high $\mathrm{V}_{\mathrm{D}} / \mathrm{V}_{\text {Tpeak }}$ and a high $\mathrm{FEV}_{1} \%$ together may synergistically amplify $\dot{V E} / \dot{V} C O 2 S$ (Fig. 2). However, $\mathrm{FEV}_{1} \%$ and $\mathrm{V}_{\mathrm{D}} / \mathrm{V}_{\text {Tpeak }}$ were negatively related in this study $(r=-0.27)$ and in a previous report $(r=-$ 0.377) [17]. As a result, the relationship between $\mathrm{FEV}_{1} \%$ and $\dot{V E} / \dot{V} C O 2 S$ was perturbed $[3,11,13]$. Hence, the relationship between $\mathrm{V}_{\mathrm{D}} / \mathrm{V}_{\text {Tpeak }}$ and $\dot{\mathrm{VE}} / \dot{\mathrm{VCO}} 2 \mathrm{~S}$ may also have been perturbed (Fig. 2 and Table 3).

Nevertheless, the high $V_{\mathrm{D}} / \mathrm{V}_{\mathrm{T}}$ was also biphasic, i.e. it caused an increase or decrease in $\dot{V} E$ at a given level of metabolism. An appropriately high $\mathrm{V}_{\mathrm{D}} / \mathrm{V}_{\mathrm{T}}$ may increase $\dot{V}$ to maintain arterial isocapnia. However, Poon and Tin [35] and Gargiuro et al. [9] reported that excessive mechanical constraints may occur in patients with $\mathrm{CHF}$ when external dead space volume is loaded to an inappropriate extent. The biphasic effect of high $\mathrm{V}_{\mathrm{D}} / \mathrm{V}_{\text {Tpeak }}$ on $\dot{V} E$ may further modify the $\dot{\mathrm{V} E} / \dot{\mathrm{VCO}} 2 \mathrm{~S}-\mathrm{FEV}_{1} \%$ relationship.

At peak exercise, the more severe the airflow obstruction and emphysema, the lower the $\mathrm{VE} / \dot{\mathrm{VCO}} 2 \mathrm{~S}[3,11$, 12]. Although Paolotti et al. [12] agreed with this notion, they proposed another two hypotheses: (1) an improvement in ventilatory efficiency during exercise due to reduced physiological dead space; (2) a higher arterial $\mathrm{CO}_{2}$ $\left(\mathrm{PaCO}_{2}\right)$ set-point, as they found that the hypercapnia was related to emphysema. In this study, the increase in $\dot{\mathrm{VE}} / \dot{\mathrm{VCO}} 2 \mathrm{~S}$ at peak exercise was related to an increase in $\mathrm{V}_{\mathrm{D}} / \mathrm{V}_{\mathrm{T}}$ but not to a decrease in $\mathrm{V}_{\mathrm{D}} / \mathrm{V}_{\mathrm{T}}$. A higher $\mathrm{P}_{\mathrm{a}} \mathrm{CO}_{2}$ point was not reset; instead, a lower $\mathrm{P}_{\mathrm{a}} \mathrm{CO}_{2}$ level developed. Notably, only 10 subjects had arterial blood gas data during exercise in their study, and the formula

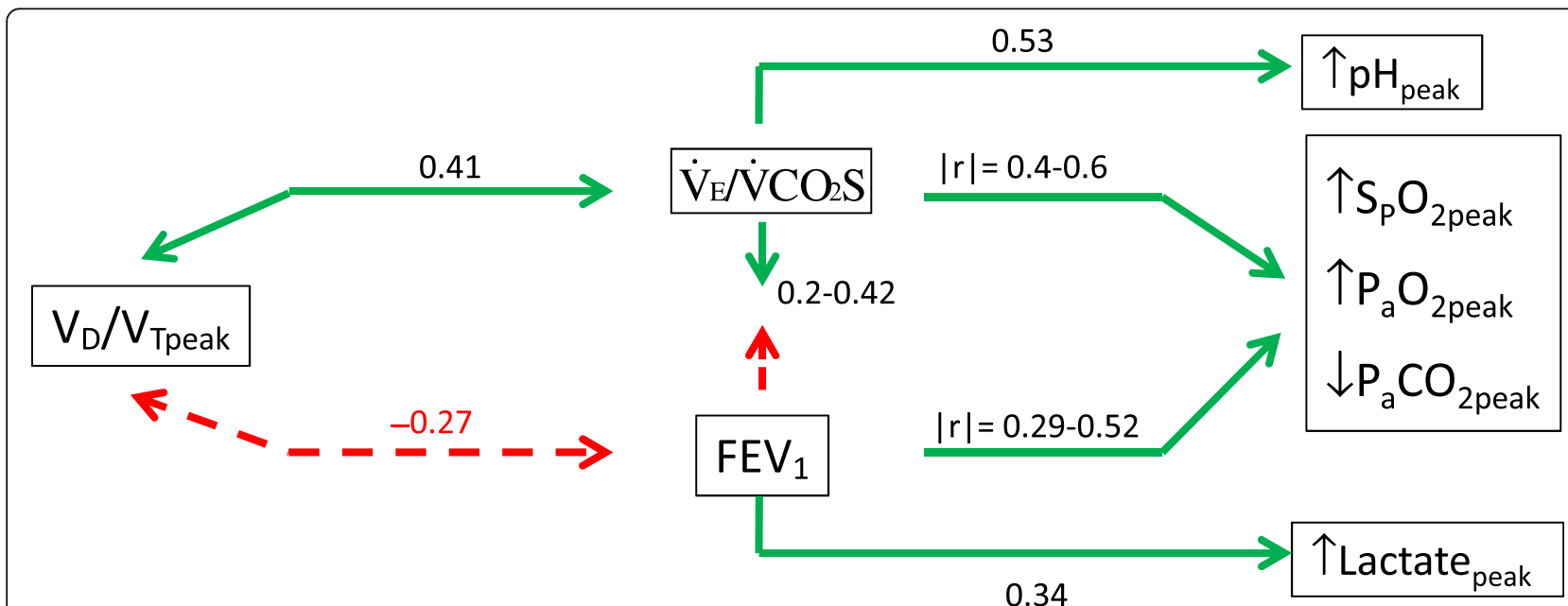

Fig. 2 Flow chart showing the deductive mechanism of exercise ventilatory inefficiency and biological homeostasis. $V_{D} / N_{T}$ : dead space fraction of tidal volume, VE/NCO2S: minute ventilation versus $\mathrm{CO}_{2}$ output slope, $\mathrm{FEV}_{1}$ : forced expired volume in one $\mathrm{S}_{1} \mathrm{~S}_{\mathrm{p}} \mathrm{O}_{2 \text { peak }}$ : oxyhemoglobin saturation measured by pulse oximetry at peak exercise, $\mathrm{P}_{\mathrm{a}} \mathrm{O}_{2}$ : arterial partial pressure of $\mathrm{O}_{2}, \mathrm{P}_{\mathrm{a}} \mathrm{CO}_{2}$ : arterial partial pressure of $\mathrm{CO}_{2}$. Solid line with twodirection arrowheads: positive correlation, dashed line with two-direction arrowheads: negative correlation. Solid line with a single direction arrowhead: positively inducing, dashed line with a single direction arrowhead: negatively inducing 
for $V_{\mathrm{D}} / \mathrm{V}_{\mathrm{T}}$ did not subtract apparatus $\mathrm{V}_{\mathrm{D}}$ [12], which was addressed by Wasserman et al. and Sun et al. [2, 30]. A high $\mathrm{FEV}_{1} \%$ is associated with a high VE; a high $\mathrm{VE}$ is associated with a high $\dot{\mathrm{VE}} / \mathrm{V} \mathrm{CO} 2 \mathrm{~S}$; a high $\mathrm{VE} / \mathrm{VCO} 2 \mathrm{~S}$ is associated with a high $\mathrm{pH}$ and $\mathrm{P}_{\mathrm{a}} \mathrm{O}_{2}$, and a low $\mathrm{P}_{\mathrm{a}} \mathrm{CO}_{2}$ (Fig. 2). In other words, this also suggests that mechanical constraints may limit the increase in $\mathrm{VE}$ during exercise with a negative influence on gas exchange values at peak exercise (i.e. $\mathrm{P}_{\mathrm{a}} \mathrm{O}_{2}$ and $\mathrm{S}_{\mathrm{P}} \mathrm{O}_{2}$ decrease, $\mathrm{P}_{\mathrm{a}} \mathrm{CO}_{2}$ increase).

Interestingly, $\mathrm{VE} / \mathrm{VCO} 2 \mathrm{~S}$ was highly negatively related to emphysema $(r=-0.77, p<0.001)$ [12] in Paolotti et al's study and in the current study as represented by $\mathrm{V}_{\text {Tpeak }} / \mathrm{FEV}_{1}$ as the emphysema factor [13] (Table 2), whereas it was moderately positively related to $V_{D} /$ $\mathrm{V}_{\text {Tpeak }}$ in the current study and in another report [16]. In this context, it can be deduced that emphysema may be inversely related to $V_{D} / V_{\text {Tpeak }}$. However, Paoletti et al. reported that when emphysema was measured by high resolution computed tomography, the $\mathrm{FEV}_{1} \%$ and $\mathrm{V}_{\mathrm{D}} / \mathrm{V}_{\text {Tpeak-rest }}$ were weakly related to the emphysema extent $[12,36]$. When emphysema was evaluated by pathology, the feature of loss of alveolar attachments was related to high $\mathrm{VD}$ and $\mathrm{V}_{\mathrm{D}} / \mathrm{V}_{\mathrm{T}}$ [37] and low $\mathrm{FEV}_{1} \%$ [17].

Volume excursion at peak exercise i.e. $\mathrm{V}_{\mathrm{T}} / \mathrm{IC}$ and $\mathrm{V}_{\mathrm{T}} /$ $\mathrm{VC}$ and $\mathrm{V}_{\mathrm{T}} / \mathrm{FEV}_{1}$ (emphysema factor) [13] and dynamic hyperinflation $(\mathrm{DH})$ as represented by $\mathrm{EELV}_{\text {peak }} / \mathrm{TLC}$ [11] have been reported to be mildly to moderately negatively related to $\mathrm{VE} / \mathrm{VCO} 2 \mathrm{~S}$ in the literature (Supplementary Table, $r=-0.31--0.35$ and $-0.48--0.60$ ). However, in the current study, even though none of the markers of volume excursion and $\mathrm{DH}$ as represented by $\mathrm{V}_{\mathrm{T}} / \mathrm{TLC}[38,39]$ were related to $\mathrm{VE} / \mathrm{VCO} 2 \mathrm{~S}$, the emphysema factor was mildly negatively related to $\mathrm{VE} / \mathrm{VCO} 2 \mathrm{~S}$ $(r=-0.32)$.

VE/VCO2I versus Pulmonary Physiology. In patients with heart failure and normal subjects with or without external $V_{D}$ at rest and during exercise, $\dot{V} E / \dot{V} C O 2 I$ is assumed to be $\dot{V D}$ when $\dot{V} C O 2$ is zero $[9,40]$. However, our findings may challenge this notion, as $\mathrm{VE} / \mathrm{VCO} 2 \mathrm{I}$ was not significantly related to $V_{D} / V_{\text {Trest }}$ or $V_{D} / V_{\text {Tpeak }}$ (Table 2). Other studies have also not supported that $\mathrm{VE} / \dot{\mathrm{VCO}} 2 \mathrm{I}$ is an index of $\mathrm{VD}$. The $\mathrm{VE} / \dot{\mathrm{VCO}} 2 \mathrm{I}$ has been reported to be $\leq 0 \mathrm{~L}$ in more than $10 \%$ of subjects in previous reports $[3,29]$ even though other studies have reported no patients with $\leq 0 \mathrm{~L}(0.9-9.9 \mathrm{~L})$ [13]. In normal subjects, Sun et al. reported a VंE/VंCO2I value of 11.7 $\mathrm{L} / \mathrm{min}$ [30]. In patients with heart failure, Gargiulo et al. reported that the average of $\mathrm{V}_{\mathrm{D}}$ and $\dot{\mathrm{V}} / \dot{\mathrm{V} C O} 2 \mathrm{I}$ at rest was $0.3-0.5 \mathrm{~L} \pm 0.2 \mathrm{~L}$, with a $\mathrm{V}_{\mathrm{T}}$ of $0.38 \pm 0.08 \mathrm{~L}$ [9]. These values are too large to be biological plausible for $V_{D}$ and $V D$ in their study [9]. Nevertheless, the apparatus $\mathrm{V}_{\mathrm{D}}$ was also not subtracted from the physiological
$V_{D}$ when calculating $V_{D} / V_{T}$ [9]. In this context, despite an increase in $\mathrm{P}_{\mathrm{ET}} \mathrm{CO}_{2}$ being moderately related to $\mathrm{VE} / \mathrm{VCO} 2 \mathrm{I}$ in the current study and to $\mathrm{VE} / \mathrm{VCO} 2 \mathrm{~S}$ in Paoletti et al's report [12], whether or not VE/VCO2I reflects VD remains unclear.

On the other hand, in the current study, we found that $\dot{V}$ /VCO2I was mildly related to inspiratory flow rather than $\mathrm{FEV}_{1} \%$ (Table 2). The loss of alveolar attachments is a feature of emphysema with high $\dot{V} D$ and $V_{D} / V_{T}$ [37] and is usually measured in fully inflated lungs so that expiratory flow obstruction cannot sufficiently reflect the condition, and thus its severity can be underestimated [41]. However, Teopompi et al. reported that VंE/VCO2I was moderately negatively related to $\mathrm{FEV}_{1} \%$ and diffusing capacity [13]. Moreover, they reported that the inconsistence in the $\mathrm{VE} / \mathrm{VCO} 2 \mathrm{I}-\mathrm{FEV}_{1} \%$ relationship was attributed to volume excursion constraint which developed during exercise [13], whereas volume excursion constraint was not related to $\mathrm{VE} / \mathrm{V} C O 2 \mathrm{I}$ or $\dot{\mathrm{VE}} / \mathrm{VCO} 2 \mathrm{~S}$ in the current study.

In the current study, the relationships between $\mathrm{VE} / \dot{\mathrm{VCO}} 2 \mathrm{~S}$ and $\dot{\mathrm{VO}} 2$ peak $\%$ and Work $_{\text {peak }} \%$ were negative to a varying extent, which is consistent with the previous reports (Table 2 and Supplementary Table) [3, 11, 13]. However, the relationship between $\mathrm{VE} / \mathrm{VCO} 2 \mathrm{I}$ and $\dot{\mathrm{VO}} 2$ peak \% in the current study was different to a previous report [11] (Table 2 and Supplementary Table). The reason is unclear. In the current study, $\mathrm{V}_{\mathrm{D}} / \mathrm{V}_{\text {Tpeak }}$ was simultaneously the opposite of $\dot{\mathrm{VE}} / \dot{\mathrm{VCO}} 2 \mathrm{I}$ and $\dot{\mathrm{VO}} 2$ peak $\%(r=-0.23$ and -0.62 , respectively $)$ and $\mathrm{V}_{\mathrm{T}} / \mathrm{T}_{\text {Ipeak }}$ was simultaneously consistent with $\mathrm{VE} / \dot{\mathrm{VCO}} 2 \mathrm{I}$ and $\mathrm{VO} 2$ ${ }_{\text {peak }} \%$ ( $r=0.22-0.30$ and 0.59 , respectively). The heterogeneity of the population of this study may also have contributed to the inconsistencies. Further studies are warranted to clarify this issue.

Lastly, an interesting finding was the difference between $\mathrm{VE} / \dot{\mathrm{VCO}} 2 \mathrm{R}$ and $\mathrm{VE} / \dot{\mathrm{VCO}} 2 \mathrm{~S}$ in combination with $\dot{\mathrm{VE}} / \dot{\mathrm{VCO}} 2 \mathrm{I}$. $\mathrm{VE} / \dot{\mathrm{VCO}} 2 \mathrm{~S}$ and $\dot{\mathrm{VE}} / \mathrm{V} \mathrm{VO} 2 \mathrm{I}$ have consistently been negatively related to a varying degree both in the current study and in previous studies (Table 2, $r=-$ 0.25 - -0.74) [11, 13]. The sum of $\dot{\mathrm{VE}} / \mathrm{VCO} 2 \mathrm{~S}$ and $\mathrm{VE} / \mathrm{VCO} 2 \mathrm{I}$ was reported to be close to or closely related to $\mathrm{VE} / \mathrm{VCO} 2 \mathrm{R}$ in a previous report [11]. In the current study, the sum of the two variables and $\mathrm{VE} / \mathrm{VCO} 2 \mathrm{R}$ were similar $(39.5 \pm 7.5$ versus $38.6 \pm 7.8, p=0.52)$. The relationship between the sum of $\mathrm{VE} / \mathrm{VCO} 2 \mathrm{~S}$ and $\mathrm{VE} / \mathrm{VCO} 2 \mathrm{I}$ and $\mathrm{VE} / \mathrm{VCO} 2 \mathrm{R}$ has been reported to be mathematical $[1,2]$. Further mathematical simulation studies on this issue are warranted.

\section{Study limitations}

There are several limitations to this study. First, correlation studies allow researchers to study the relationships 
between one variable and others, and may not be appropriate to infer a cause and effect. However, it is reasonable to consider that a high $\mathrm{V}_{\mathrm{D}} / \mathrm{V}_{\mathrm{T}}$ may induce $\mathrm{VE} / \mathrm{VCO} 2 \mathrm{~S}$ rather than to consider that a high $\dot{\mathrm{V}} / \mathrm{V} \mathrm{VO} 2 \mathrm{~S}$ induces a high $\mathrm{V}_{\mathrm{D}} / \mathrm{V}_{\mathrm{T}}$. Similarly, a high $\mathrm{FEV}_{1} \%$ may induce a high $\mathrm{VE} / \mathrm{VCO} 2 \mathrm{~S}$ rather than a high $\mathrm{VE} / \mathrm{VCO} 2 \mathrm{~S}$ induces a high FEV1\%. Second, the number of cases in this subgroup study was small, and this may have caused insufficient power when performing correlation coefficient analysis on $\mathrm{V}_{\mathrm{D}} / \mathrm{V}_{\mathrm{T}}$ and the other variables of interest. However, the sample size of 46 achieved a power of $80 \%$ to detect a difference between a correlation of 0.4 and the null (no correlation) using a two-sided test with a significance level of 0.05 . As the power is related to type II error, a nonsignificant test results should be interpreted more conservatively. Third, all of the participants in this study were male, so the results cannot be applied to females. As only $4 \%$ of patients with COPD are female in Taiwan [20], and as breathing pattern and dead space are different between men and women [42], it would be difficult to enroll a sufficient number of female subjects with COPD to compare the differences between male and female patients with COPD. To calculate $\dot{\mathrm{VE}} / \dot{\mathrm{VCO}} 2 \mathrm{~S}$ and $\dot{\mathrm{VE}} / \mathrm{VCO} 2 \mathrm{I}$, the methodology to identify VCP or RCP $[1,9,29]$ and whether to use the entire loaded exercise data [5] or data below VCP/RCP $[2,3,11-13]$ are inconsistent in the literature. Further studies are warranted to clarify these issues.

\section{Clinical implication}

Although airflow obstruction may attenuate the increase in $\dot{V E} / \dot{V} C O 2 S$ during incremental exercise, an increase in dead space ventilation may amplify $\dot{\mathrm{V}} / \mathrm{V} \mathrm{CO} 2 \mathrm{~S}$ and thus perturb the $\dot{\mathrm{VE}} / \mathrm{VCO} 2 \mathrm{~S}-\mathrm{FEV}_{1} \%$ relationship. Nevertheless, airflow obstruction is usually accompanied with increased dead space ventilation. Hence, this study reveals the paradoxical relationship among the three factors (i.e. $\dot{V}$ / $\mathrm{VCO} 2 \mathrm{~S}$, airflow obstruction and dead space ventilation). The role of $\mathrm{VE} / \mathrm{VCO} 2 \mathrm{I}$ as a marker of ventilatory insufficiency in COPD is also questionable. Further studies are warranted to study the clinical applications and importance of exercise $\mathrm{VE} / \mathrm{VCO} 2 \mathrm{~S}$ and $\dot{\mathrm{VE}} / \mathrm{VCO} 2 \mathrm{I}$ in patients with COPD.

\section{Conclusions}

Using $V_{D} / V_{T}$ measurements, we found that dead space ventilation perturbs the airflow- $\dot{\mathrm{VE}} / \mathrm{V} \mathrm{CO} 2 \mathrm{~S}$ relationship. Increasing ventilation thereby increasing $\mathrm{VE} / \mathrm{VCO} 2 \mathrm{~S}$ may be the cause rather than the effect of maintaining biological homeostasis. The pulmonary physiology- $\dot{\mathrm{VE}} / \dot{\mathrm{VCO}} 2 \mathrm{~S}-\dot{\mathrm{VE}} / \dot{\mathrm{V} C O} 2 \mathrm{I}$ relationship is inconsistent between the current study and previous studies.

\section{Supplementary information}

Supplementary information accompanies this paper at https://doi.org/10. 1186/s12931-020-01463-4.

Additional file 1: Supplementary Table. Summary of correlation ( $r$ ) of $V^{\cdot} E / V^{\cdot} \mathrm{CO} 2$ slope $\left(V^{\cdot} E / V^{\cdot} \mathrm{CO} 2 S\right)$ and its intercept $\left(V^{\cdot} E / V^{\cdot} \mathrm{CO} 2 l\right)$ with pulmonary physiology.

Additional file 2.

\section{Abbreviations}

VE: Ventilation; $\dot{V} C O 2$ : $\mathrm{CO}_{2}$ output; $\mathrm{V}_{\mathrm{D}} \mathrm{N}_{\mathrm{T}}$ : Dead space fraction of tidal volume;

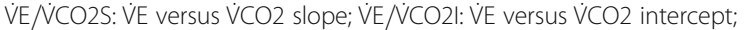
$\mathrm{FEV}_{1} \%$ : Forced expired volume in one $\mathrm{s} \%$ predicted; CHF: Congestive heart failure; COPD: Chronic obstructive pulmonary disease; VE/VCO2R: VE/VCO2 ratio; GOLD: Global Initiative for Chronic Lung Disease; FVC: Forced vital capacity; CPET: Cardiopulmonary exercise test; OCD: Oxygen-cost diagram; TLC: Total lung capacity; RV: Residual volume; $\mathrm{D}_{\mathrm{L}} \mathrm{CO}$ : Diffusing capacity for carbon monoxide; $\mathrm{P}_{\mathrm{ET}} \mathrm{CO}_{2}$ : End-tidal $\mathrm{PCO}_{2} ; \mathrm{S}_{\mathrm{P}} \mathrm{O}_{2}$ : Arterial oxyhemoglobin saturation was measured by pulse oximetry; RCP or VCP: Respiratory or ventilatory compensation point; $\dot{V}$ /VCO2N: $\dot{V}$ / NCO2 nadir

\section{Acknowledgements}

I thank Professor Lin, I-Feng of National Yang Ming University, Institute of Public Health, for her comments on statistical analysis.

The name of the institution(s) review board: The Institutional Review Board of Chung Shan Medical University Hospital.

\section{Author's contributions}

MLC: initiated and designed the study, analyzed and interpreted the data, wrote the manuscript, and approved the version to be published.

\section{Funding}

This study was supported in part by Chung Shang Medical University Hospital. The funding body had no role in the design of the study and collection, analysis, and interpretation of data and in writing the manuscript. This study was supported in part by the Minister of Science and Technology, Taiwan.

\section{Availability of data and materials}

Uploaded.

\section{Ethics approval and consent to participate}

Signed informed consent was obtained from each participant. The local Institutional Review Boards of the two institutions approved this study. The name of the ethics committee: Chung Shan Medical University Hospital (CS19014).

Registered at this site: Chung Shan Medical University Hospital, Taichung,

Taiwan.

Registration number: CSH-2019-C-030.

Studies involving animals: "Not applicable".

Consent for publication

"Not applicable".

Competing interests

The authors declare no competing financial interests.

Received: 13 June 2020 Accepted: 22 July 2020

Published online: 06 August 2020

\section{References}

1. Wasserman K, Hansen JE, Sue DY, Stringer WW, Whipp BJ. Measurements during integrative cardiopulmonary exercise testing. In: Wasserman $\mathrm{K}$, editor. Principles of exercise testing and interpretation. 4th ed. Philadelphia: Lippincot Williams \& Wilkins; 2005. p. 76-110.

2. Wasserman K, Hansen JE, Sue DY, Stringer WW, Whipp BJ. Normal values. In: Wasserman $K$, editor. Principles of exercise testing and interpretation. 4th ed. Philadelphia: Lippicott Williams \& Wilkins; 2005. p. 160-82. 
3. Teopompi E, Tzani P, Aiello M, et al. Ventilatory response to carbon dioxide output in subjects with congestive heart failure and in patients with COPD with comparable exercise capacity. Respir Care. 2014;59(7):1034-41.

4. Arena R, Myers J, Abella J, et al. Influence of heart failure etiology on the prognostic value of peak oxygen consumption and minute ventilation/ carbon dioxide production slope. Circulation. 2007;115(18):2410-7.

5. Tabet JY, Beauvais F, Thabut G, Tartière JM, Logeart D, Cohen-Solal A. A critical appraisal of the prognostic value of the VENCO2 slope in chronic heart failure. Eur J Cardiovasc Prev Rehabil. 2003;10(4):267-72.

6. Kim V, Kretschman DM, Sternberg AL, DeCamp MMJ, Criner GJ. National Emphysema Treatment Trial Research Group. Weight gain after lung reduction surgery is related to improved lung function and ventilatory efficiency. Am J Respir Crit Care Med. 2012:186(11):1109-16.

7. Metra M, Raccagni D, Carini G, et al. Ventilatory and arterial blood gas changes during exercise in heart failure. In: Wasserman K, editor. Exercise gas exchange in heart failure. 1st ed. Armonk: Futura; 1996. p. 125-43.

8. Koike A, Hiroe M, Marumo F. Increased ventilatory response to exercise as related to functional capacity. In: Wasserman K, editor. Exercise gas exchange in heart disease. 1st ed. Armonk, Futura; 1996. p. 109-23.

9. Gargiulo P, Apostolo A, Perrone-Filardi P, Sciomer S, Palange P, Agostoni P. A non invasive estimate of dead space ventilation from exercise measurements. PLoS One. 2014;9(1):e87395.

10. Whipp BJ, Ward SA, Wasserman K. Ventilatory control to exercise and their control in man. Am Rev Respir Dis. 1984;129(2 Pt 2):S17-20.

11. Neder JA, Arbex FF, Alencar MC, et al. Exercise ventilatory inefficiency in mild to end-stage COPD. Eur Respir J. 2015;45(2):377-87.

12. Paoletti $P$, De Filippis F, Fraioli F, et al. Cardiopulmonary exercise testing (CPET) in pulmonary emphysema. Respir Physiol Neurobiol. 2011;179(2-3): 167-73.

13. Teopompi E, Tzani P, Aiello M, Gioia MR, Marangio E, Chetta A. Excess ventilation and ventilatory constraints during exercise in patients with chronic obstructive pulmonary disease. Respir Physiol Neurobiol. 2014;197: 9-14.

14. Gagnon P, Bussières JS, Ribeiro F, et al. Influences of spinal anesthesia on exercise tolerance in patients with chronic obstructive pulmonary disease. Am J Respir Crit Care Med. 2012;186(7):606-15.

15. Peters MM, Webb KA, O'Donnell DE. Combined physiological effects of bronchodilators and hyperoxia on exertional dyspnoea in normoxic COPD. Thorax. 2006;61(7):559-67.

16. Jones NL, Berman LB. Gas exchange in chronic air-flow obstruction. Am Rev Respir Dis. 1984;129(2 Pt 2):S81-S3.

17. Wright JL, Cagle P, Churg A, Colby TV, Myers J. Diseases of the small airways. Am Rev Respir Dis. 1992;146(1):240-62.

18. Wasserman K, Hansen JE, Sue DY, Stringer WW, Whipp BJ. Physiology of exercise. In: Wasserman K, editor. Principles of exercise testing and interpretation. 4th ed. Philadelphia: Lippicott Williams \& Wilkins; 2005. p. 1065.

19. GOLD Committees. Global Strategy for the Diagnosis, Management, and Prevention of Chronic Obstructive Pulmonary Disease (revised 2015). Disclosure forms for GOLD Committees are posted on the GOLD Website, wwwgoldcopdorg 2017.

20. Huang TH, Hsiue TR, Lin SH, Liao XM, Su PL, Chen CZ. Comparison of different staging methods for COPD in predicting outcomes. Eur Respir J. 2018;51(3).

21. Chuang $M L$, Lin IF, Lee CY. Clinical assessment tests in evaluating patients with chronic obstructive pulmonary disease - a cross-sectional study. Medicine (Baltimore). 2016;95(47):e5471.

22. Chuang ML, Lin IF. Investigating the relationships among lung function variables in chronic obstructive pulmonary disease in men. Peer J. 2019;7: e7829.

23. Chuang ML, Lin IF, Wasserman K. The body weight-walking distance product as related to lung function, anaerobic threshold and peak VO2 in COPD patients. Respir Med. 2001;95(7):618-26.

24. Miller MR, Hankinson J, Brusasco V, et al. Standardisation of spirometry. Eur Respir J. 2005;26(2):319-38.

25. Wanger J, Clausen $\mathrm{J}$, Coates A, et al. Standardisation of the measurement of lung volumes. Eur Respir J. 2005;26(3):511-22.

26. ATS/ERS S. ATS/ERS statement on respiratory muscle testing. Am J Respir Crit Care Med. 2002;166(4):518-624.

27. Miller MR, Crapo R, Hankinson J, et al. General considerations for lung function testing. Eur Respir J. 2005;26(1):153-61.
28. Chuang ML, Lee $\mathrm{CH}$, Lin IF. Using the oxygen-cost diagram in ramp-slope selection for dyspneic patients. Intern Med. 2010;49(14):1325-32.

29. American Thoracic Society, American College of Chest Physicians. ATS/ACCP statement on cardiopulmonary exercise testing. Am J Respir Crit Care Med. 2003;167(2):211-77.

30. Sun XG, Hansen JE, Garatachea N, Storer TW, Wasserman K. Ventilatory efficiency during exercise in healthy subjects. Am J Respir Crit Care Med. 2002;166(11):1443-8.

31. Wasserman K, Hansen JE, Sue DY, Stringer WW, Whipp BJ. Calculations, formulas, and examples. In: Wasserman K, editor. Principles of exercise testing and interpretation. 4th ed. Philadelphia: Lippincot Williams \& Wilkins; 2005. p. 556-65

32. Vassilakopoulos T, Zakynthinos S, Roussos C. Assessing muscular oxygenation during incremental exercise using near-infrared spectroscopy: comparison of three different methods. Am J Respir Crit Care Med. 1998; 158(2):378-85

33. Zocchi L, Fitting JW, Majani U, Fracchia C, Rampulla C, Grassino A. Effect of pressure and timing of contraction on human rib cage muscle fatigue. Am Rev Respir Dis. 1993;147(4):857-64.

34. Bégin P, Grassino A. Chronic Alveolar Hypoventilation Helps To Maintain the Inspiratory Muscle Effort of COPD Patients Within Sustainable Limits. Chest. 2000:117(5 Suppl 1):271S-3S.

35. Poon CS, Tin C. Mechanism of augmented exercise hyperpnea in chronic heart failure and dead space loading. Respir Physiol Neurobiol. 2013;186(1): 114-30.

36. Kurashima K, Takayanagi N, Sato N, et al. High resolution $C T$ and bronchial reversibility test for diagnosing COPD. Respirology. 2005;10(3):316-22.

37. Nici L. Mechanisms and measures of exercise intolerance in chronic obstructive pulmonary disease. Clin Chest Med. 2000;21(4):693-704.

38. Chuang ML. Combining dynamic hyperinflation with dead space volume during maximal exercise in patients with chronic obstructive pulmonary disease. J Clin Med. 2020;9(10):1127.

39. Chuang ML, Hsieh MJ, Lin IF. Developing a new marker of dynamic hyperinflation in patients with obstructive airway disease - an observational study. Sci Rep. 2019;9(1):7514.

40. Agostoni P, Apostolo A, Sciomer S. Evolution of the concept of ventilatory limitation during exercise. Combining the pneumologist and cardiologist point of view. Respir Physiol Neurobiol. 2011;179(2-3):127-8.

41. Thurlbeck WM. Pathophysiology of chronic obstructive pulmonary disease. Clin Chest Med. 1990;11(3):389-403.

42. Gläser S, Ittermann T, Koch B, et al. Influence of smoking and obesity on alveolar-arterial gas pressure differences and dead space ventilation at rest and peak exercise in healthy men and women. Respir Med. 2013;107(6): 919-26.

\section{Publisher's Note}

Springer Nature remains neutral with regard to jurisdictional claims in published maps and institutional affiliations.
Ready to submit your research? Choose BMC and benefit from:

- fast, convenient online submission

- thorough peer review by experienced researchers in your field

- rapid publication on acceptance

- support for research data, including large and complex data types

- gold Open Access which fosters wider collaboration and increased citations

- maximum visibility for your research: over $100 \mathrm{M}$ website views per year

At $\mathrm{BMC}$, research is always in progress.

Learn more biomedcentral.com/submissions 